\title{
Effectiveness of childbirth classes in reducing anxiety before birth depending on age and education
}

\section{Efektywność szkoły rodzenia $w$ redukcji lęku przed porodem w zależności od wieku i wyksztatcenia}

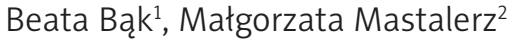 \\ 'Department of Perinatology and Gynecological-Obstetrical Nursing, Institute of Nursing and Obstetrics, Faculty of Medicine \\ and Health Science, Jan Kochanowski University, Kielce, Poland \\ Head of the Department: Prof. JKU Marek Sikorski MD, PhD \\ 2Delivery Room, Swietokrzyskie Centre for Mothers and Newborns, Specialized Hospital, Kielce, Poland \\ Head of the Room: Andrzej Witczak MD, PhD
}

Key words: anxiety, birth, childbirth school.

Słowa kluczowe: lęk, poród, szkoła rodzenia.

\begin{abstract}
Introduction: Pregnancy and childbirth are among the most special moments in women's lives, but are sometimes associated with negative emotions. In many cases, the fear of childbirth leads to a request to perform a caesarean section. Aim of the research: To evaluate the subjective opinion on the perceived fear of childbirth and the effectiveness of participation in childbirth classes depending on the age and education of women surveyed.

Material and methods: The questionnaire study included 125 women in the antepartum period involved in antenatal classes. Statistical analysis was performed using the $\chi^{2}$ test.

Results: Women aged 40 and older felt the most fear of childbirth. Those with secondary education were least afraid of childbirth. Those with vocational and higher education had the greatest fear. Women of all ages in the majority were wholly or partly satisfied with participating in Lamaze classes. However, a large percentage of the group of 20-30 years and over 40 years could not use in practice the knowledge and skills gained during the course. The level of education statistically significantly contributed to applying in practice the knowledge and skills obtained in the Lamaze classes.

Conclusions: There was a relationship between age and education of women and fear of childbirth. Education differentiates ability to apply in practice the knowledge and skills learned in Lamaze classes. Despite the benefits of participation in the course, one should pay more attention to skills training and implementation of the acquired knowledge and skills.
\end{abstract}

\section{Streszczenie}

Wprowadzenie: Ciąża i poród to szczególne momenty w życiu kobiety. Niekiedy są one związane z negatywnymi emocjami. W wielu przypadkach lęk przed porodem staje się przyczyną, że kobiety życzą sobie zakończenia ciąży cięciem cesarskim. Cel pracy: Ocena subiektywnych opinii na temat odczuwanego lęku przed porodem, a także ocena efektywności udziału w zajęciach szkoły rodzenia w zależności od wieku i wykształcenia badanych kobiet.

Materiał i metody: Badaniem za pomocą ankiety objęto 125 położnic uczestniczących przed porodem w zajęciach szkoły rodzenia. Wyniki poddano analizie statystycznej za pomocą testu $\chi^{2}$.

Wyniki: Kobiety powyżej 40 lat odczuwały najsilniejszy lęk przed porodem. Najmniej poród przerażał kobiety ze średnim wykształceniem. Największy lęk stwierdzono u badanych z wykształceniem zawodowym oraz wyższym. Kobiety we wszystkich grupach wiekowych były zdecydowanie usatysfakcjonowane udziałem w szkole rodzenia. Wśród kobiet w wieku 20-30 lat oraz powyżej 40 lat duży był odsetek tych, które nie potrafiły wdrożyć w życie wiedzy i umiejętności zdobytych podczas zajęć. Stopień wykształcenia w istotny statystycznie sposób wpłynął na wykorzystanie w praktyce wiedzy i umiejętności uzyskanych w szkole rodzenia. Istnieje zależność pomiędzy wiekiem i wykształceniem kobiet a lękiem przed porodem. Wykształcenie różnicuje wykorzystanie w praktyce wiedzy i umiejętności zdobytych w szkole rodzenia.

Wnioski: Pomimo korzyści, jakie daje udział w kursie, należy zwrócić większą uwagę na trening umiejętności wprowadzenia w życie uzyskanej wiedzy i umiejętności. Modyfikacja programu przyczyni się do redukcji negatywnych emocji, a także uwzględni potrzeby wszystkich uczestników kursu. 


\section{Introduction}

Pregnancy and childbirth are critical moments in women's lives [1]. Experiences of joyful anticipation can sometimes be accompanied by negative emotions, mainly in the form of fear of childbirth [2, 3]. These emotions may in some women cause in future mental disorders in the form of anxiety, lack of selfcontrol and security, and be the cause of postpartum depression [4]. In addition, fear of childbirth during pregnancy may pose a risk of preterm delivery, low birth weight newborn, high blood pressure, and prolonged childbirth. It is mainly the reason women request a caesarean, and the cause of implementation of this emergency delivery [5-7]. Studies in the UK show that the number of women who fear childbirth is increasing in successive generations [8]. It has been proven that negative emotions associated with childbirth are present in $20-30 \%$ of women [2, 3]. Italians most often are afraid of not being in control of their own behavior in the delivery suite. The Swiss, Hungarian, Finns and Poles fear such a course of labor may endanger the health of their child as well as themselves [8]. Soet et al. argue that for $34 \%$ of women childbirth is a traumatic event and in $1.9 \%$ it leads to post-traumatic stress disorder [3].

Since the beginning of the twentieth century among some doctors and midwives caring for pregnant women and the women giving birth there has been a view that the contractions under physiological conditions are painless. The starting point is the fear of pain that increases tension and leads, by insufficient oxygenation of tissues, to pain. Anxiety can be removed by appropriate education and tension by relaxation. These beliefs led to psycho-obstetrics, on the basis of which today antenatal classes exist. They are supposed to prepare the pregnant woman and her partner to actively participate in the act of birth of their baby and allay the fear of impending birth. The birth of instrumental character is replaced with "the art of giving birth" [9]. Childbirth education equips participants with resources of resistance to stress, which according to Antonovsky include information resources and practical skills [10].

\section{Aim of the research}

The aim of the study was to evaluate subjective opinion on the perceived fear of childbirth by women giving birth, as well as to evaluate the effectiveness of participation in antenatal classes depending on the age and education of women surveyed.

\section{Material and methods}

The study using a proprietary survey included 125 women giving birth for the first time participating in VITA antenatal classes operating at the Swietokrzyskie Center for Mothers and Newborns in Kielce.

\section{Statistical analysis}

The results were analyzed statistically for measurable traits' compliance with the $\chi^{2}$ test. For statistical inference the level of significance was $p<0.05$.

\section{Results}

The largest group participating in Lamaze classes $(57.6 \%)$ consisted of women aged 31-40 years; there were slightly fewer $(26.4 \%)$ women in the age group 20-30 years. The fewest were very young women under 20 years of age and older women above 40 years (respectively 7.2\% and 8.8\%). Higher education dominated $(66.4 \%)$, while $20 \%$ of respondents had secondary education. The fewest (13.6\%) were women with vocational education (Table 1 ).

Table 2 shows the results that have been confirmed statistically $(p=0.04)$. Only $11.2 \%$ of respondents under 20 years of age had reduced anxiety as they approach childbirth. Such a response was not observed in any other age groups. Replies from other respondents under 20 look the same: $22.2 \%$ of women claimed that fear grew the closer was the date of birth, the greatest fear was felt during the labor and felt no fear at all. The same number of respondents had no opinion. In the age group 20-30 years in more than $2 / 3$ the greatest anxiety occurred during labor. In every fifth respondent anxiety grew the closer was the term. $27.3 \%$ of women felt no fear at all. About $12.1 \%$ of women had no opinion. Similar trends were observed in the age group 31-40 years. Almost half (48.6\%) felt the greatest fear during labor. Twenty-five percent felt no fear at all, and in every fifth woman fear was greater as the final phase of labor was approaching. 5.6\% of respondents had no opinion. Women over 40 years of age anxiety felt most strongly during the labor. In 36.4\% anxiety increased as they become closer to childbirth, while for only $18.2 \%$ anxiety was a strange feeling.

Statistical analysis confirmed the relationship of education with the perceived fear of childbirth $(p=0.002)$. As many as $29.4 \%$ of women with vocational education felt the strongest anxiety during labor. In a slightly smaller group (23.5\%), anxiety grew as it approached childbirth. Only $17.6 \%$ felt no fear at

Table 1. Characteristics of study group $(n=125)$

\begin{tabular}{|llcc|}
\hline $\begin{array}{l}\text { Characteristic of women } \\
\text { surveyed - participants } \\
\text { of the school of childbirth }\end{array}$ & $\boldsymbol{N}$ & Percentage \\
Age & Below 20 years & 9 & \\
& 20-30 years & 33 & 26.4 \\
& 31-40 years & 72 & 57.6 \\
Education & Over 40 years & 11 & 8.8 \\
& Vocational & 17 & 13.6 \\
& Secondary & 25 & 20.0 \\
& Higher & 83 & 66.4 \\
\hline
\end{tabular}


Table 2. Perceived fear of childbirth depending on age

\begin{tabular}{|c|c|c|c|c|c|c|c|c|}
\hline \multirow[t]{3}{*}{ Level of anxiety before the childbirth } & \multicolumn{8}{|c|}{ Age } \\
\hline & \multicolumn{2}{|c|}{$\begin{array}{l}\text { Under } 20 \\
\text { years old }\end{array}$} & \multicolumn{2}{|c|}{$\begin{array}{c}20-30 \\
\text { years old }\end{array}$} & \multicolumn{2}{|c|}{$\begin{array}{c}31-40 \\
\text { years old }\end{array}$} & \multicolumn{2}{|c|}{$\begin{array}{l}\text { Over } 40 \\
\text { years old }\end{array}$} \\
\hline & $n=9$ & $\%$ & $n=33$ & $\%$ & $n=72$ & $\%$ & $n=11$ & $\%$ \\
\hline Fear decreased as I approached childbirth & 1 & 11.1 & 0 & 0 & 0 & 0 & 0 & 0 \\
\hline Anxiety increased the closer it was to term & 2 & 22.2 & 7 & 21.2 & 15 & 20.8 & 4 & 36.4 \\
\hline for only $18.2 \%$ anxiety was a strange feeling. & 2 & 22.2 & 13 & 39.4 & 35 & 48.6 & 5 & 45.4 \\
\hline I felt the greatest fear during labor & 2 & 22.2 & 9 & 27.3 & 18 & 25.0 & 2 & 18.2 \\
\hline No opinion & 2 & 22.2 & 4 & 12.1 & 4 & 5.6 & 0 & 0 \\
\hline$P$-value & \multicolumn{8}{|c|}{0.04} \\
\hline$\chi^{2}$ test (calculated figure) & \multicolumn{8}{|c|}{21.41} \\
\hline$\chi^{2}$ test (value array) & \multicolumn{8}{|c|}{21.03} \\
\hline
\end{tabular}

Table 3. Perceived fear of childbirth depending on education

\begin{tabular}{|c|c|c|c|c|c|c|}
\hline \multirow[t]{3}{*}{ Level of anxiety before the childbirth } & \multicolumn{6}{|c|}{ Education } \\
\hline & \multicolumn{2}{|c|}{ Vocational } & \multicolumn{2}{|c|}{ Secondary } & \multicolumn{2}{|c|}{ Higher } \\
\hline & $n=17$ & $\%$ & $n=25$ & $\%$ & $n=83$ & $\%$ \\
\hline Fear decreased as I approached childbirth & 1 & 5.9 & 0 & 0 & 0 & 0 \\
\hline Anxiety increased the closer it was to term & 4 & 23.5 & 6 & 24.0 & 14 & 16.9 \\
\hline I felt the greatest fear during labor & 5 & 29.4 & 5 & 20.0 & 45 & 54.2 \\
\hline I felt no fear at all & 3 & 17.6 & 10 & 40.0 & 21 & 25.3 \\
\hline No opinion & 4 & 23.5 & 4 & 16.0 & 3 & 3.6 \\
\hline$P$-value & \multicolumn{6}{|c|}{0.002} \\
\hline$\chi^{2}$ test (calculated figure) & \multicolumn{6}{|c|}{24.02} \\
\hline$\chi^{2}$ test (value array) & \multicolumn{6}{|c|}{15.51} \\
\hline
\end{tabular}

all and, in an even smaller percentage (5.9\%), anxiety decreased as they approached childbirth. Almost one in four women had no opinion on the subject. Forty percent of respondents with secondary education declared that they felt no fear of childbirth at any stage of pregnancy and labor. In almost every fifth anxiety grew as it approached childbirth and one in four felt the strongest anxiety during labor. Among women with higher education no reduction of anxiety was observed as they approached the date of birth. The most common (54.2\%) greatest fear was present during the birth, one in four did not feel fear at all, and in $16.9 \%$ anxiety increased as they approached the birth (Table 3)

Although the statistical results do not support dependence on age of the degree of use in practice the knowledge and skills acquired in Lamaze classes $(p=0.36), 44 \%$ of women under 20 years of age benefited fully from them. $22.2 \%$ of respondents were unable to take advantage of the acquired knowledge and skills during later labor. $11.1 \%$ partially made use of them in practice. More than every fifth respondent did not express any opinion. In the age group 20-30 years women, in whole or in part, benefited from the Lamaze course (respectively 36.3\% and 30.4\%). Every fifth negatively referred to the possible use of classes in practice. The same was true in the age group 31-40 years, where $41.7 \%$ fully used what they learned in antenatal classes, $33.3 \%$ fully and only $15.3 \%$ was not able to put the acquired knowledge into practice. Among women over 40 years of age, $36.4 \%$ of the respondents fully took advantage of the classes and only 9.1\% did it partially. Quite a large percentage (27.3\%) was unable to take advantage of the classes. The same percentage had no opinion on the subject (Table 4).

As shown in Table 5, the level of education statistically significantly ( $p=0.0002$ ) affects the use in practice of the knowledge and skills learned in Lamaze classes. $47.1 \%$ of women with vocational and $48.2 \%$ with higher education made use of them in full. In 
Table 4. Knowledge and skills learned in Lamaze classes used in practice depending on age

\begin{tabular}{|c|c|c|c|c|c|c|c|c|}
\hline \multirow{3}{*}{$\begin{array}{l}\text { Knowledge and skills learned in Lamaze } \\
\text { classes put into practice }\end{array}$} & \multicolumn{8}{|c|}{ Age } \\
\hline & \multicolumn{2}{|c|}{$\begin{array}{l}\text { Under } 20 \\
\text { years old }\end{array}$} & \multicolumn{2}{|c|}{$\begin{array}{l}20-30 \\
\text { years old }\end{array}$} & \multicolumn{2}{|c|}{$\begin{array}{l}31-40 \\
\text { years old }\end{array}$} & \multicolumn{2}{|c|}{$\begin{array}{l}\text { Over } 40 \\
\text { years old }\end{array}$} \\
\hline & $n=9$ & $\%$ & $n=33$ & $\%$ & $n=72$ & $\%$ & $n=11$ & $\%$ \\
\hline Total & 4 & 44.4 & 12 & 36.3 & 30 & 41.7 & 4 & 36.4 \\
\hline Yes, but only partially & 1 & 11.1 & 10 & 30.4 & 24 & 33.3 & 1 & 9.1 \\
\hline $\begin{array}{l}\text { I could not use the knowledge and skills } \\
\text { learned in Lamaze classes }\end{array}$ & 2 & 22.2 & 8 & 24.2 & 11 & 15.3 & 3 & 27.3 \\
\hline No opinion & 2 & 22.2 & 3 & 9.1 & 7 & 9.7 & 3 & 27.3 \\
\hline$P$-value & \multicolumn{8}{|c|}{0.36} \\
\hline$\chi^{2}$ test (calculated value; the value of an array) & \multicolumn{8}{|c|}{9.87} \\
\hline$\chi^{2}$ test (array value) & \multicolumn{8}{|c|}{16.92} \\
\hline
\end{tabular}

Table 5. Knowledge and skills acquired in Lamaze classes used in practice depending on education

\begin{tabular}{|c|c|c|c|c|c|c|}
\hline \multirow{3}{*}{$\begin{array}{l}\text { Knowledge and skills acquired in Lamaze classes } \\
\text { put into practice }\end{array}$} & \multicolumn{6}{|c|}{ Education } \\
\hline & \multicolumn{2}{|c|}{ Vocational } & \multicolumn{2}{|c|}{ Secondary } & \multicolumn{2}{|c|}{ Higher } \\
\hline & $n=17$ & $\%$ & $n=25$ & $\%$ & $n=83$ & $\%$ \\
\hline Total & 8 & 47.1 & 2 & 8.0 & 40 & 48.2 \\
\hline Yes, but only partially & 2 & 11.8 & 6 & 24.0 & 27 & 32.5 \\
\hline $\begin{array}{l}\text { I could not use the knowledge and skills } \\
\text { learned in Lamaze classes }\end{array}$ & 4 & 23.5 & 12 & 48.0 & 8 & 9.6 \\
\hline No opinion & 3 & 17.6 & 5 & 20.0 & 8 & 9.6 \\
\hline$P$-value & \multicolumn{6}{|c|}{0.0002} \\
\hline$\chi^{2}$ test (calculated value; the value of an array) & \multicolumn{6}{|c|}{26.10} \\
\hline$\chi^{2}$ test (array value) & \multicolumn{6}{|c|}{12} \\
\hline
\end{tabular}

addition, $32.5 \%$ of those with higher education partially utilized during childbirth previously acquired information and skills. The worst knowledge was observed in the group of women with secondary education, where as many as $48 \%$ of respondents did not know how to use childbirth classes in practice, and about every fifth used them as a whole. Eight percent in this group benefited from the course in its entirety. What is worrying is the fact that $23.5 \%$ of respondents were unable to use information and skills gained during the course.

\section{Discussion}

Experiences of joy and happiness because of a newborn baby are emotions expected of young mothers. However, for some of them pregnancy and childbirth are a major disappointment and leave behind painful, traumatic memories. Precursors of research on emotional experiences accompanying pregnancy and childbirth are Dunbar and Squier [11]. In the follow- ing years it has been proven that psychological stress can cause premature childbirth and other obstetric complications [12]. One of the tasks of antenatal classes recommended by the Polish Gynecological Society is to prevent unpleasant emotions associated with pregnancy and childbirth through education and skills training to prepare for motherhood [13].

The results of this study show that most participants of antenatal classes were women aged 31-40 years with higher education. Slightly different results for age were obtained by Kwiatek et al., studying the demographic profile of women attending antenatal classes held at the Department of Obstetrics and Pathology of Pregnancy, Medical University of Lublin [14]. According to the authors, the majority were pregnant at the age of 25-30 years, while the smallest group - here no diference was observed - consisted of those pregnant under 25 years of age. As in our work, women with higher education prevailed among all respondents. Kołomyjec et al. found that the average 
age of primiparous subjects participating in antenatal classes was 27.7 years and 32.5 years for multiparous. More than half of all those surveyed had a higher education, and more than one third a secondary education. Basic education was only reported by $2.5 \%$ of pregnant women, and vocational 5.9\% [15]. On the basis of these data, and on the basis of the presented results, a special emphasis on health promotion and promoting the idea of antenatal classes should apply among the youngest mothers and those above 40 years of age and among women with secondary and vocational education.

There is now a tendency to postpone motherhood to a later period of women's life. In connection with the change of lifestyle, pregnancy after age 30 is very popular nowadays. It is believed that higher age (30-40 years) does not qualify the women to be in the group at high risk, because a lot depends on the mode of life, general health and individual predisposition [16]. Budrowska believes that the reduction of maternal mortality and neonatal modern methods of infertility treatment and dealing with health problems give women more and more certainty that in the later period of their life they will be able to become mothers of healthy children [17]. The results show a low percentage of participants of antenatal classes under the age of 21 years. Caus et al. believed that the lack of education of young people in the planning of pregnancy and delivery causes a low percentage or non-participation in antenatal class activities among women in this age. In these same studies, the authors emphasize that interest in the program which offers antenatal increases with the level of education [18]. A woman educated better understands the necessity of good preparation for motherhood.

Anxiety during pregnancy can lead to premature births and low birth weight. Lobel et al. studied women who gave birth before 37 weeks' gestation and those with infant birth weight not exceeding $2500 \mathrm{~g}$. They found that anxiety related to pregnancy and childbirth was correlated with smoking, drinking large amounts of coffee, irrational nutrition and lack of physical activity [19]. It has been shown that a sense of fear during pregnancy and childbirth is related to the behavior of infants who are more anxious compared with infants of mothers not experiencing negative emotions [20]. Taghizadeh et al. in research on the sources of anxiety before birth they gave a sense of helplessness when confronted with the new situation, a new environment, concern about the lack of control over an anticipated birth and loneliness. These feelings cause lack of confidence in women. Negative emotions according to the authors can occur at any stage of pregnancy and during childbirth, and their research has shown that the majority of mothers felt fear throughout pregnancy. The same authors, summarizing the results of their research, concluded that it concerned mostly experiencing the act of childbirth and the state of the child. It was so significant that it influenced the decision about the next pregnancy. The intensity of the fear felt meant that $10 \%$ of the women demanded a caesarean section. The decision about surgery was mainly driven by the fear of pain during labor [21]. Many authors in the study of anxiety related to pregnancy and childbirth found that $11 \%$ of Swedish, 5.3\% of Swiss and 78\% of Finnish women felt very strong fear for their child [22-24]. It has also been shown that fear of childbirth is conditioned by age, education, economic situation of women, culture and the state of medical care [25].

According to the presented results of the research into the interrelation between the fear of giving birth and the age of pregnant women participating in antenatal classes, older women often felt more fear during the course of labor and as they approached the birth than women under 20 years of age. Moreover, in the youngest age group for $11.2 \%$ anxiety decreased as they approached the date of birth. Almost every fourth respondent claimed that she felt no fear at all, which is not recorded in any other age groups. Studies assessing the level of antenatal anxiety in pregnant women physiological conducted by Bączyk et al. showed that older women (over 35 years old) show a higher level of anxiety than younger ones. They point out however that moderate fear of birth is beneficial for the course of childbirth, especially for co-operation for a woman who is giving birth [26]. Piela et al. have shown that elevated levels of anxiety before birth occur in women between 18 and 35 years of age, while in women below and above this age group they are low [27].

More than half of the surveyed women with higher education felt fear during active labour or just as labour was upcoming. Small differences in the assessment of anxiety were presented by a group of women with vocational education. Only a group of women with secondary education in the majority claimed that they felt no fear at all. Alipour et al. in research on anxiety during pregnancy and childbirth proved that women frequently experience anxiety as they approached the date of birth. In addition, those at 28 and 38 weeks of gestation identified anxiety as strong; more often than others they feared the impending birth. According to the authors, strong fear of childbirth is very often finished by emergency caesarean and the use of large quantities of painkillers [28]. Fenwick et al., investigating the source and modifying factors of anxiety experienced during childbirth, pointed to the low level of education on the subject, the negative experiences described by other women, negative experience in previous deliveries, lack of control over their own reactions and the inability to make decisions [29].

The English obstetrician GD Read, creator of the idea of antenatal classes, stated that during childbirth anxiety causes an increase in muscle tone, which en- 
hances the perception of pain and leads to increased anxiety, medically known as a vicious circle of disease. To break this circle the pregnant woman must be informed about the course of childbirth and be told clearly what she can expect [30]. Women applying for an antenatal course are searching for knowledge of pregnancy, childbirth and the childbed period and expect education in the skills of taking care of a newborn. They want to consciously participate in the childbirth, and allay the concerns and fears of pain and what is unknown [31]. The presented results indicate that regardless of age, in the Kielce classes of the school of childbirth, most of the participants put the knowledge acquired during the course into practice fully or partially. However, in the oldest group of women (over 40 years old), a relatively large group did not benefit from the knowledge and skills offered by the classes, claiming that they could not use all the knowledge that had been taught in the delivery suite. The same trend has been noted in the group of younger women (under 20 years of age). These data suggest that the program of the courses should include the needs of the oldest and youngest women, and involve all the pregnant women much more during the courses.

Respondents with vocational and higher education in the majority in whole or in part made use of the knowledge and skills gained during birth classes. But for almost half of the women with secondary education there was characteristic inability to implement in life the educational resources gained during the course. In this group, only a few have used these resources as a whole. It should also be noted that difficulties in the use of knowledge and skills acquired in childbirth classes were experienced by nearly one quarter of women with vocational education. Fabian et al., in research on the effectiveness of antenatal classes, found that $74 \%$ of participants in practice applied knowledge and skills gained on the course, while $40 \%$ of women felt that the school had prepared them to give birth and for early parenthood [32].

The research results presented in this paper inefficiencies in antenatal classes in which pregnant women participated. It is therefore necessary to modify the course itself so as to contribute to the reduction of negative emotions, and also take into account the needs of all age groups of participants. Maybe you should take into account a greater role for the psychologist, who will be able to equip participants with techniques for coping with the stress of pregnancy and that accompanies the pregnancy childbirth. An interesting proposal, existing since 1994 in Canada, the US and Sweden, is group prenatal care (GPC), run by midwives on the basis of support groups connected with education about pregnancy and childbirth. Meetings with pregnant women in a similar gestational age and their partners are held at regular time intervals starting from the $28^{\text {th }}$ week. The frequency of these meetings increases with the approaching date of birth. During the course participants, in addition to the principles of healthy behaviors during pregnancy, consciously participate in childbirth and newborn care, learn how to perform a blood pressure measurement, interpret results of measurement of body weight and the use of tests to detect the presence of protein in the urine, and the choice of topics is agreed with the interested parties. Psychoprophylaxis for pregnancy and delivery involves sharing your emotions, experiences and concerns. The atmosphere of classes is to help foster partnerships between two people expecting a child, between individual pairs and between the pairs and midwives. It also teaches the practical implementation of the acquired knowledge and skills, which, as the results show, the Kielce course lacked, perhaps for the reason of the large size of the group. In principle, the purpose of the GPC is to provide the leaders with health information for pregnant women, and persons accompanying them learn to look at the situation through the eyes of mothers and derive maximum satisfaction from their work $[33,34]$. In Canada, a survey was conducted on GPC participants of the course. They were mostly positive. They pointed to the possibility of contact with other pregnant women (knowing that it continued after the end of the pregnancy), thereby reducing the sense of isolation, the atmosphere of mutual trust, the small group size, strengthening self-esteem and symptoms of treatment [35].

The benefits of completing the Lamaze course depend not only on the individual characteristics of the participants, but also on the knowledge, skills and commitment of people running the course. An interesting solution that supplements a childbirth school, is provided by a complementary helpline for pregnant women run by midwives. Such an institution was introduced in Australia. Women at any time can benefit from free advice on topics related to pregnancy, childbirth and future puerperium. They can also share their emotions. The effectiveness of psychoeducational intervention is expressed in the reduction of numbers of caesarean sections and emotional consequences that may be associated with a traumatic birth [36]. Fewer requests for a caesarean section, and the low level of anxiety associated with childbirth, were noted by Aksoy et al., proving that these phenomena are associated with obtaining reliable knowledge about natural childbirth methods of pain relief [37].

The Lamaze course should place more emphasis on the ability to use personal resources to protect against negative emotions. Taheri et al. conducted a study among pregnant women with weekly sessions conducted by midwives and doctors, in order to arouse faith in its effectiveness, ability to verbalize their feelings, acting out negative emotions and positive motivation. The results showed that high levels of self-efficacy achieved by actions of psychopreven- 
tions and education cause that women prefer vaginal birth and the forces of nature and are less likely to demand cesarean section [38]. In turn, Butler et al. are of the opinion that prenatal care involving education and psychological support contributes to more effective and longer breastfeeding [39]. A greater role is therefore justified for a psychologist in antenatal classes or equipping midwives with the skills for communication therapy and supportive psychotherapy.

The most important thing is the subjective opinion of the participants of Lamaze classes. The analysis of opinions should be conducted systematically, and all the conclusions should be used to modify curricula and adapt them to the current needs of the participants. Raising skills and updating knowledge of people running antenatal classes is essential for their effective functioning.

\section{Conclusions}

There is a relationship between age and the subjective assessment of the fear of childbirth among participants of the childbirth classes. The older the woman is, the more likely she is to experience anxiety as she approaches the birth or during it. This means that, older women, younger women need more mental support and activity in order to increase their awareness and capabilities.

Fear of childbirth depends on the degree of education. Women with secondary education are least afraid of childbirth. The biggest fear is presented by women with vocational and higher education. It covers the period before birth and birth itself. Less fear is not associated with either a higher or lower level of education. Women with higher education as well as women with vocational education require greater attention in order to reduce their fear of childbirth.

Lamaze classes do not contribute to reducing anxiety as they approach childbirth regardless of age and education of the participants.

Most women, regardless of age, entirely or partly used the knowledge and skills learned in Lamaze classes. However, one should particularly pay attention to skill training implementation resources acquired during the course, because there is a large group of women, of all ages, who could not use the acquired knowledge and skills in the delivery suite.

The degree of education is significant in putting into practice the knowledge and skills acquired in childbirth classes. This course is best utilized by women with vocational and higher education. Antenatal classes should focus more on people with a secondary education.

The results presented in the work indicate inefficiencies in antenatal classes in which pregnant women participated. The program must be modified so that it contributes to the reduction of negative emotions, while taking into account the needs of all participants.

\section{Conflict of interest}

The authors declare no conflict of interest.

\section{References}

1. Cigoli V, Gili G, Saita E. Relational factors in psychopathological responses to childbirth. J Psychosom Obstet Gynaecol 2006; 27: 91-97.

2. Beck CT, Watson S. Subsequent childbirth after a previous traumatic birth. Nurs Res 2010; 59: 241-9.

3. Soet JE, Brack GA, Dilorio C. Prevalence and predictors of women's experience of psychological trauma during childbirth. Birth 2003; 30: 36-46.

4. Harris R, Ayers S. What makes labour and birth traumatic? A survey of intrapartum 'hostpots'. Psychol Health 2012; 27: 1166-77.

5. Hernandez-Martinez C, Arija V, Balaguer A, Cavallé P, Canals J. Do the emotional states of pregnant women affect neonatal behaviour? Early Hum Dev 2088; 84: 745-50.

6. Johnson R, Slade P. Does fear of childbirth during pregnancy predict emergency caeserean section? BJOG 2002; 109: 1213-21.

7. Ryding EL, Wijma B, Rydhstrom H. Fear of childbirth during pregnancy may increase the risk of emergency cesarean section. Acta Obstet Gynecol Scand 1998; 77: 542-7.

8. Fijałkowski W. Szkoła rodzenia. PZWL, Warsaw 1977.

9. Horney K. Neurotyczna osobowość naszych czasów. PWN, Warsaw 1992.

10. Antonovsky H, Sagy S. The development of a sense of coherence and its impact on responses to stress situations. J Soc Psychol 1986; 126: 213-25.

11. Squier R, Dunbar F. Emotional factors in the course of pregnancy. Psychosom Med 1946; 8: 161-75.

12. Motyka M. Psychologiczne uwarunkowania powikłań położniczych. Gin Pol 1982; 53: 431-5.

13. Rekomendacje Zarządu Głównego PTG w zakresie opieki przedporodowej w ciąży o prawidłowym przebiegu. Ginekologia po Dyplomie 2005; Wyd. specjalne, grudzień 2005.

14. Kwiatek M, Gęca T, Biegaj-Fic J, Kwaśniewska A. Szkoła rodzenia - profil pacjentek oraz wpływ zajęć na przebieg porodu i stan noworodka. Med Og Nauki Zdr 2011; 17: 111-5.

15. Kołomyjec P, Suchocki S, Kędra-Rakoczy M. Wykształcenie i zachowania prozdrowotne ciężarnych biorących udział w zajęciach szkoły rodzenia oraz ich wpływ na przebieg porodu i stan noworodka. Klin Piernat Gin 2007; 43: 57-60.

16. Caplan AL, Patrizio P. Are you ever too old to have a baby? The ethical challenges of older women using infertillity services. Semin Repod Med 2010; 28: 281-6.

17. Budrowska B. Macierzyństwo jako punkt zwrotny w życiu kobiety. Monografie FNP, Warsaw 2000.

18. Caus I, Mazurek M, Kamińska J, Kielar P, Brząkali D. Szkoły rodzenia województwa śląskiego etapem edukacji rodzinnej. Zdr Publ 2002; 112: 62-4.

19. Lobel M, Cannella DL, Graham JE, DeVincent C, Schneider J, Meyer BA. Pregnancy-specific stress, prenatal health behaviors, and birth outcomes. Health Psychol 2008; 27: 604-15.

20. Sawada N, Gagne FM, Seguin L, Kramer MS, McNamara H, Platt RW, Goulet L, Meaney MJ, Lydon JE. Maternal prenatal felt security and infant health at birth interact to predict infant fussing and crying at 12 month postpartum. Health Psychol 2015; 34: 811-9. 
21. Taghizadeh Z, Irajpour A, Nedjat S, Arbabi M, Lopez V. Iranian mothers' perception of the psychological birth trauma: a qualitative study. Iran J Psychiatry 2014; 9: 31-6.

22. Melender HL, Lauri S. Experiences of security associated with pregnancy and childbirth: a study of pregnant women. Int Nurs Pract 2002; 8: 289-96.

23. Geissbuehler V, Eberhard J. Fear of childbirth during pregnancy: a study of more than 8000 pregnant women. Psychosom Obsted Gynaecol 2002; 23: 229-35.

24. Saisto T, Halmensmaki E. Fear of childbirth: a neglected dilemma. Acta Obstet Gynaecol Scand 2003; 82: 2001-208.

25. Ayers S, Pickering AD. Do women get posttraumatic stress disorder as a result of childbirth? A prospective study of incidence. Birth 2001; 28: 111-8.

26. Bączyk G, Cebulska V, Koźlak V, Michalak M, Bajek A, Marcinkowski JT. Poziom lęku przedporodowego u kobiet w ciąży. Probl Hig Epidemiol 2011; 92: 774-7.

27. Piela B, Skrzypulec V, Sobik N. Ocena objawów depresji i lęku u kobiet w ciąży podwyższonego ryzyka. Ann Acad Med Siles 2005; 59: 292-97.

28. Alipour Z, Lamyian M, Hajizadeh E, Vafaei MA. The association between antenatal anxiety and fear of childbirth in nulliparous women. A prospective study. Iran J Nurs Midwifery Res 2011; 16: 169-73.

29. Fenwick J, Tooohill J, Creedy DK, Smith J, Gamble J. Sources, responses and moderators of childbirth fear in Australian women: a qualitative investigation. Midwifery 2015; 31: 239-46.

30. Read GD. The principles and practice of natural childbirth. Heineman, London 1951

31. Iwanowicz-Palus G, Pawelec A. Organizacja i funkcjonowanie szkół rodzenia w Polsce. V Ogólnopolski Zjazd Szkół Rodzenia, Jurata 2005.

32. Fabian HM, Radestad IJ, Waldenström U. Childbirth and parenthood education classes in Sweden. Women's opinion and possible outcomes. Acta Obstet Gynecol Scand 2005; 84: 436-43.

33. Walker DS, Worrell R. Promoting healthy pregnancies through perinatal groups: a comparison of Centering Pregnancy (R) group prenatal care and childbirth education classes. J Perinat Educ 2008; 17: 27-34.

34. Mc Neil DA, Vekved M, Dolan SM, Siever J, Horn S, Tough SC. A qualitative study of the experience of Centering Pregnancy group prenatal care for physicians. BMC Pregnancy Childbirth 2013; Suppl 1: S6.

35. Mc Donald S, Sword W, Eryuzlu LE, Biringer AB. A qualitative study of the group prenatal care experience: perceptions of women with low-risk pregnancies and their midwives. BMC Pregnancy Childbirth 2014; 14: 334.

36. Toohill J, Fenwick J, Gamble J, Creedy DK, Buist A, Turkstra E, Ryding EL. A randomized controlled Trial of a Psycho-Education Intervention by Midwives in reducing fear in pregnant women. Birth 2014; 41: 384-94.

37. Aksoy M, Aksoy AN, Dostbil A, Celik MG, Ince I. The relationship between fear of childbirth and women's knowledge about painless childbirth. Obstet Gynecol Int 2014; 2014: 274303

38. Taheri Z, Mazaheri MA, Khorsandi M, Hassanzadeh A, Amiri M. Effect of education intervention on self-efficacy for choosing delivery method among pregnant women in 2013. Int J Prev Med 2014; 5: 1247-54.
39. Butler MM, Sheely L, Kingdon MM, Walsh MC, Brosnan MC, Murphy M, Naughton C, Drennan J, Barry T. Evaluating midwife-led antenatal care: choice, experience, effectiveness, and preparation for pregnancy. Midwifery 2015; 31: 418-25.

\section{Address for correspondence:}

\section{Beata Bąk MD}

Department of Perinatology and Gynaecological-Obstetrical Nursing

Faculty of Health Science Jan Kochanowski University al. IX Wieków Kielc 19, 25-317 Kielce, Poland

Phone: +48 692113477

E-mail: beatab5@onet.eu 